\title{
Spotting senile systemic amyloidosis: why we miss it
}

\author{
Marianna Fontana ${ }^{1 *}$, Cristina C Quarta ${ }^{1}$, Janet Gilbertson ${ }^{1}$, Thirusha Lane ${ }^{1}$, Carol J Whelan ${ }^{1}$, Julian D Gillmore ${ }^{1}$, \\ Philip N Hawkins ${ }^{1}$, James C Moon ${ }^{2}$ \\ From First European Congress on Hereditary ATTR amyloidosis \\ Paris, France. 2-3 November 2015
}

\section{Objectives}

To analyze the geometric pattern of cardiac hypertrophy in patients with wild-type transthyretin amyloidosis (wtATTR, formerly called senile amyloid) using cardiovascular magnetic resonance (CMR) and to analyze the diagnostic implications.

\section{Background}

wtATTR amyloidosis is an under-diagnosed and underappreciated cause of heart failure. CMR adds value diagnostically for morphological phenotype and tissue characterization.

\section{Methods}

At a national referral centre, over 4 years, 87 consecutive recruited patients wtATTR amyloidosis underwent CMR. The diagnosis was confirmed by histological proof of amyloid (62\%), exclusion of TTR mutations (100\%) and characteristic features including bone tracer scanning (DPD grade 2-3 in 100\%). CMR had precipitated the referrals in $71 \%$ of the cohort. Standard long and short axis cines derived the presence and distribution of $\mathrm{LVH}$, relative wall thickness (RTW), inversion of the septal curvature and LV remodeling patterns were determined.

\section{Results}

There were 82 patients with wt ATTR amyloidosis (82 males (94\%), age $75 \pm 7$ years). Patients with wtATTR amyloidosis had increased LV mass index, EF at the lower limit of normal range and markedly reduced indexes of longitudinal function. LV mass was always large compared to cavity size, as expected. However there was far more asymmetric hypertrophy than expected $-61 \%$ of patients had the septum $>1.5 \mathrm{x}$ thicker

${ }^{1}$ National Amyloidosis Centre, UCL, NW3 2QG, London, UK

Full list of author information is available at the end of the article than the posterior wall. Inversion of the septal curvature was found in $34 \%$ of patients, features typically associated with hypertrophic cardiomyopathy. Tissue characterization with LGE was typical of amyloidosis in $100 \%$ of cases (transmural LGE in 73\%, subendocardial in 27\%).

\section{Conclusions}

CMR is a major source of diagnosis of wtATTR. The majority of patients with wtATTR amyloidosis have a pattern of hypertrophy traditionally thought associated with hypertrophic cardiomyopathy rather than amyloid with asymmetric septal hypertrophy and reverse septal curvature.

\section{Authors' details}

${ }^{1}$ National Amyloidosis Centre, UCL, NW3 2QG, London, UK. ${ }^{2}$ Barts Heart Centre, Barts Hospital, E2 9JX, London, UK.

Published: 2 November 2015

doi:10.1186/1750-1172-10-S1-P51

Cite this article as: Fontana et al: Spotting senile systemic amyloidosis: why we miss it. Orphanet Journal of Rare Diseases 2015 10(Suppl 1):P51.

Submit your next manuscript to BioMed Central and take full advantage of:

- Convenient online submission

- Thorough peer review

- No space constraints or color figure charges

- Immediate publication on acceptance

- Inclusion in PubMed, CAS, Scopus and Google Scholar

- Research which is freely available for redistribution 